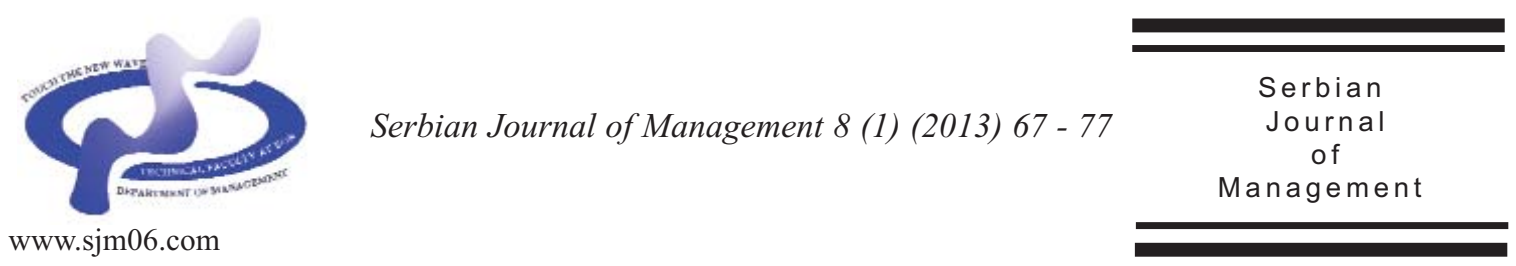

\title{
HAS THE BOLOGNA PROCESS IMPROVED MASTER'S EDUCATION STANDARDS? PERSPECTIVES OF ALBANIAN EMPLOYERS
}

\author{
Vasilika Kume and Zhaklina Dhamo \\ University of Tirana, \\ Kutia Postare Nr 183 / Dëshmorët e Kombit Street, Tirana, Albania
}

(Received 7 January 2013; accepted 2 March 2013)

\begin{abstract}
In this research the professional innovation of the Master studies as per Bologna Process standards, observed from the possible buyers of such product, the Albanian Employers is studied. With the help of a survey, it has been tried to reflect the opinion of the employers about the quality of a Master degree according to the standarts of the Bologna Process. Around 53\% of the employers think that the Bologna system can qualitatively improve the employee's qualification, but this should be observed in a long-term horizon. About $87 \%$ of employers would not pay more a prospective employee given the fact that he/she has earned a master degree according the Bologna Process standards. This individual, in the majority of Albanian companies, would not be considered as more qualified than other colleagues who are educated in another system. Moreover, $20 \%$ of employers with work experience 11-15 years believe that the Bologna Process worsens the quality of education in Albania.
\end{abstract}

Keywords: Higher Education, Bologna Process, Albanian Employers, Personnel Management, Firm Employment Decisions

\section{INTRODUCTION}

Since the fall of communism, the Albanian system of education has been gradually liberalized. In the last decade, many private schools including primary, secondary, high schools and universities emerged. For this reason, there was a need for education standards. In this line of thinking, from 2003 to 2010 in most of the universities was adopted the Bologna Process. This academic system seems to be widely accepted from most universities in the European Union.

\footnotetext{
*Corresponding author: zhaklina86@yahoo.com
}

DOI: $10.5937 /$ sjm8-3038 
To assess the empirical effectiveness of this education system, in this research is studied the view of the purchaser of such system, the Albanian employers. It was developed a questionnaire and it was delivered in many Albanian companies, in order to comprehend the effectiveness of the Bologna Process master degrees in the improvement of employee's skills. The results are noteworthy. About $90 \%$ of the employers in this survey would not employ a young student just because he/she had a master degree in accordance with the Bologna Process vis-à-vis another employee who had a master degree not in accordance with the Bologna Process. This process seems far from convincing the buyers of this product, the Albanian employers.

This research continues with a short description of the Bologna Process, which is further specified in the subsequent section for Albania. Then, the research methodology description is presented. The general analyses of the results come afterwards. One specific group analyses of recruiters with relatively high work experience follows. In the end, the conclusions of this paper are presented.

\section{SHORT DESCRIPTION OF THE BOLOGNA PROCESS}

The Bologna Process aims to facilitate the movement of students throughout Europe, acknowledging the periods of studies inside and outside the country of origin. This is achieved through the implementation of the instruments such as: European Credit Transfer and Accumulation System (ECTS) and Diploma Supplement.

These instruments are employed for the improving of transparency in the European
Higher Education Universities, making possible that the programs and degrees offered in one country be comprehended and recognized in another country of the European Union.

\section{THE BOLOGNA PROCESS IN ALBANIA}

The Bologna Declaration was signed by Albanian authorities on September 2003. Based on 2010's Law for Higher Education of the Republic of Albania, the diploma earned in the first cycle of studies is named Bachelor. The diplomas earned in the second cycle of higher education studies are named "Master". This legal framework is adopted by almost all higher education institutions, public and private, in Albania.

\section{LITERATURE REVIEW}

During June-July 2005, a few years after the sign of the Bologna Declaration from Albanian authorities, the Institute of International Studies (AIIS), in cooperation with Soros Foundation, made a survey, one of the purposesof this survey was the comprehension of the informing level of Albanian citizens about Bologna Process. The participants of the survey were mainly the academic community in Albania. According to the results published, about 60$65 \%$ of the respondents (1500 respondents answered to the survey) had not well grounded information about the process. Students who were in the first year of study and academics were not well informed about the reforms undertaken in higher education (AIIS, 2005). 
Further, in a study from Qefalia and Totoni, through questionnaires and interviews directed to academics in the public universities in Albania, it is concluded that Continious Quality Improvement usage is strongly positively correlated to accreditation and the Bologna Process with a level of confidence 95\% (Qefalia \& Totoni, 2012).

Taking a view to experience of other Balkan countries with similar background as Albania, in a study from Dima et al., assessing the academic staff perception in Romania regarding the Bologna Process trade off, they conclude that funding for implementation of the Bologna Process in universities can be an issue. This contributes the slowdown and not proper implementation of a set of rules and regulations that would allow such academic institutions close the gap between them and other universities that have adopted this system, and take all adtvantages (Dima et al., 2011).

Moreover, in an article by Ian Wylie at the Financial Times, citing Paul Gaston, trustees profesor at Kent State University in US, he states "Initially, the interests of the Bologna process were at odds with those of the business schools community worldwide... More recently, given the interest expressed by the European ministers in emphasising co-operation over competition, there may be greater opportunity for tharing of best practices among business schools worldwide" (as cited at Wylie, 2010).

In his article, Wylie states also the developed countries such as France and Germany have been timely accurate in implementing the changes of the Bologna Process. In eastern Europe, however, as Wylie states, "governments have used the accord as an opportunity for reinventing universities stuck in the communist era" (Wylie, 2010).

As stated by Professor Guido Tabellini, rector at Bocconi University, Milan, the standartisation implied by the Bologna Process has nott completely succeeded, due to the fact that implementation has not succeeded yet to all EU contries. This fact restricts student mobility (Financial Times, 2010).

In the same article, Bernard Ramanantsoa, Dean of HEC Paris, claims that, due to the Bologna Process, all students from European business schools have spent at least one academic term abroad (Financial Times, 2010).

In this paper, differently from the above mentioned articles, it is not chosen the assessment of the suppliers of the academic system (academics), but it is chosen to quantify and analyse the opinion of the demand of such academic system (Albanian employers).

\section{METHODOLOGY}

The best way to asses the quality of a product is to test the demand in the market. If the product is higher education qualification in Albania, the buyers of this product are most probably the Albanian employers. Education has also social and cultural impact and can be exported. These aspects, due to the focus of this study, are not taken into consideration. In this line of thinking, it was developed a survey with the purpose to reflect the opinion of the employers of private companies in Albania about the quality of a Master degree diploma of an institution that has adapted the standarts of the Bologna Process. The employers in this survey are represented by the human 
resource managers, sole owners of the business, CEOs. For simplicity, this group of individuals will be addressed with the term "employers" or "recruiters".

This questionaire (Appendix A) identifies some characteristics of the recruiters in the Albanian companies, such as age, gender, education, work experience, etc. It has to be emphasized the fact that it was believed useful to observe the gender statistics of employers/employees in recruiting positions for the companies that participated at this survey. Therefore, it was useful to analyse the gender that dominates the survey in this study.

Another important characteristic in this study is employers' age, since different agegroups have different ways of thinking. For this reason, recruiters are devided into five age-groups.

It is considered important for this study the level of education of the employers, since it influences the opinion regarding the quality of a master degree. Such opinion is also influenced by the information about the work experience and job switch frequency.

The information level of the employers about the Bologna Process is one of the most important feedback regarding the goals of this survey. To reach proper conclusions, the last three questions underline recruiters' opinion about a master degree according to the Bologna Process. The objective is to analyze the assessment of the Albanian employers about the quality of a master degree as per the Bologna Process standarts.

\section{GENERAL ANALYSIS OF THE RESULTS}

The questionnaire was sent to over 50 companies and groups of Albanian companies. These companies represent different sectors of the economy such as energy, construction, investment, distribution, food industry, textile industry, heavy industry. Also, some of these companies engage in various service activities such as telecommunication, banks, financial institutions, logistics, marketing, postal services etc.

Only 30 companies responded. All the statistical and qualitative analysis is based on 30 completed questionnaires. The respondents are anonymous as a precondition of filling the questionnaire. However, it is thought that most of economic sectors are well represented in this survey.

Table 1 shows the statistics of the answers of all questions in the questionnaire in Appendix A. The rows represent the questions of the questionnaire, while the columns represent the answers (alternatives) for each question. Combinations of rows and columns are the results for each possible choice. The results are expressed as a ratio in percentage of completed questionnaires with a specific response to a specific question divided by the total number of questionnaires completed, that is 30 .

The first thing that drives attention from Table 1 , is the fact that the number of females who completed the survey $(73.33 \%)$ dominates the number of males $(26.67 \%)$. We can say that executives of companies seem to prefer female recruiters, but we are not aware the extent to which the sample companies that responded this survey, represent the Albanian overall private sector. This assumption is valid for every analysis of the survey.

An interesting outcome of this questionnaire is that there is no respondent under the age of 26. There is an almost equal number of employers in the age group 26-30 
years $(33.33 \%), 31-35$ years $(26.67 \%)$ and $36-40$ years $(23.33 \%)$, which gives the perception for a need of experienced but also youthful energies in such positions.

Regarding education, statistics that are reflected in the answers of the third question, it clearly shows that all recruiters have at least a bachelor degree $(66.67 \%)$. Hence, this fact may imply that the evaluation of employee candidates with diverse academic qualification probably should be assigned to individuals of a comparable intellectual capacity with the latter.

It seems to be important for all companies the work experience of recruiters. As per the answers provided in Question 4, according to Table 1, more than $75 \%$ of recruiters have more than 5 years of experience. The explanation may stand in the communication skills and psychoanalytical ability that individuals with more work experience possess.

Based on the answer to question five, recruiters in this survey, in $40 \%$ of cases, have changed from 2 to 3 times job.
Promotion to such positions of professionals who have experienced diverse work experience may show the need for flexible and discrete recruiters from a broader perspective for the human resources of a company.

The staff performance assessment of Albanian companies, based in the answer to question 6 , is done every seven months to one year from most of them $(70 \%)$. This means that each worker is reassessed/promoted/downgraded/stand by once a year. The significance of this result regarding the objective of this paper lies in intuition that recruiters are updated once a year in most cases with academic qualification developments in Albania.

According to the summary of answers to question $7,53 \%$ of recruiters that completed this survey have general knowledge about the Bologna Process. This result is consistent with the analysis of the informing level of the Albanian Academic Community regarding the Bologna Process stated above. If a conceptual comparison is to be made, six

Table 1. Descriptive Statistics of the answers of all questions included in the questionnaire in Appendix A. The rows represent the questions of the questionnaire, while the columns represent the choices (alternatives) for each question. Combinations of rows and columns are the results for each possible choice.

\begin{tabular}{|c|c|c|c|c|c|}
\hline & Answer 1 & Answer 2 & Answer 3 & Answer 4 & Answer 5 \\
\hline Question 1 & $73,33 \%$ & $26,67 \%$ & & & \\
\hline Question 2 & $0,00 \%$ & $33,33 \%$ & $26,67 \%$ & $23,33 \%$ & $16,67 \%$ \\
\hline Question 3 & $0,00 \%$ & $0,00 \%$ & $66,67 \%$ & $33,33 \%$ & $0,00 \%$ \\
\hline Question 4 & $0,00 \%$ & $23,33 \%$ & $20,00 \%$ & $36,67 \%$ & $20,00 \%$ \\
\hline Question 5 & $13,33 \%$ & $26,67 \%$ & $40,00 \%$ & $20,00 \%$ & $0,00 \%$ \\
\hline Question 6 & $6,67 \%$ & $16,67 \%$ & $70,00 \%$ & $6,67 \%$ & $0,00 \%$ \\
\hline Question 7 & $3,33 \%$ & $6,67 \%$ & $53,33 \%$ & $36,67 \%$ & $0,00 \%$ \\
\hline Question 8 & $13,33 \%$ & $23,33 \%$ & $53,33 \%$ & $10,00 \%$ & \\
\hline Question 9 & $26,67 \%$ & $0,00 \%$ & $10,00 \%$ & $63,33 \%$ & $0,00 \%$ \\
\hline Question 10 & $86,67 \%$ & $3,33 \%$ & $10,00 \%$ & $0,00 \%$ & $0,00 \%$ \\
\hline
\end{tabular}


years later (2011) prospective buyers of this system (Albanian companies) have general knowledge similarly as the sellers of it (Albanian academics) had five years ago.

The most important results of this survey rely on the answers to question 8, 9 and 10 . Based on these respondents of question 8 , $53 \%$ of the employers think that the Bologna system can qualitatively improve the Albanian education level, but this should be observed in a long-term horizon. This result may be interpreted as current uncertainty about the innovation/stagnation outcomes of the adaption of the Bologna Process from most higher education institutions in Albania, since Albanian employers do not seem confident regarding its effectiveness in the job market. The latter is suggested by the parallelism described in the last paragraph, where employers simply assume they have general knowledge about this higher education system. Interestingly, $10 \%$ of recruiters believe that the Bologna system worsens the Albanian higher education quality. This result may be an important incentive for more research.

Only $10 \%$ of employers would prefer an employee given the fact that he/she has earned a master degree according the
Bologna Process standards. This result may suggest a lack of overall acknowledgment of the Bologna Process in the Albanian labour market. It may be the result of the uncertainty due to lack of information or the non-existence of the difference in quality between an individual who is qualified with a Master Degree as per Bologna Process and someone who is qualified under another education system. About $63 \%$ of the employers have answered that the difference in quality does not rely on the education system, but on individual skills. Maybe the result can be explained by the inability to understand the difference and it may be too soon for the labour market to distinguish the real values of this system. However, such result stands critical towards Bologna Process and its implementation in Albania.

Following the intuition above, based on answers to question $10,87 \%$ of recruiters would not pay more an employee just because he/she is qualified by a master degree as per Bologna system. This result monetizes what analysed in the previous paragraphs.

In other words, an individual who has earned a master degree in accordance with the Bologna Process standards, in the

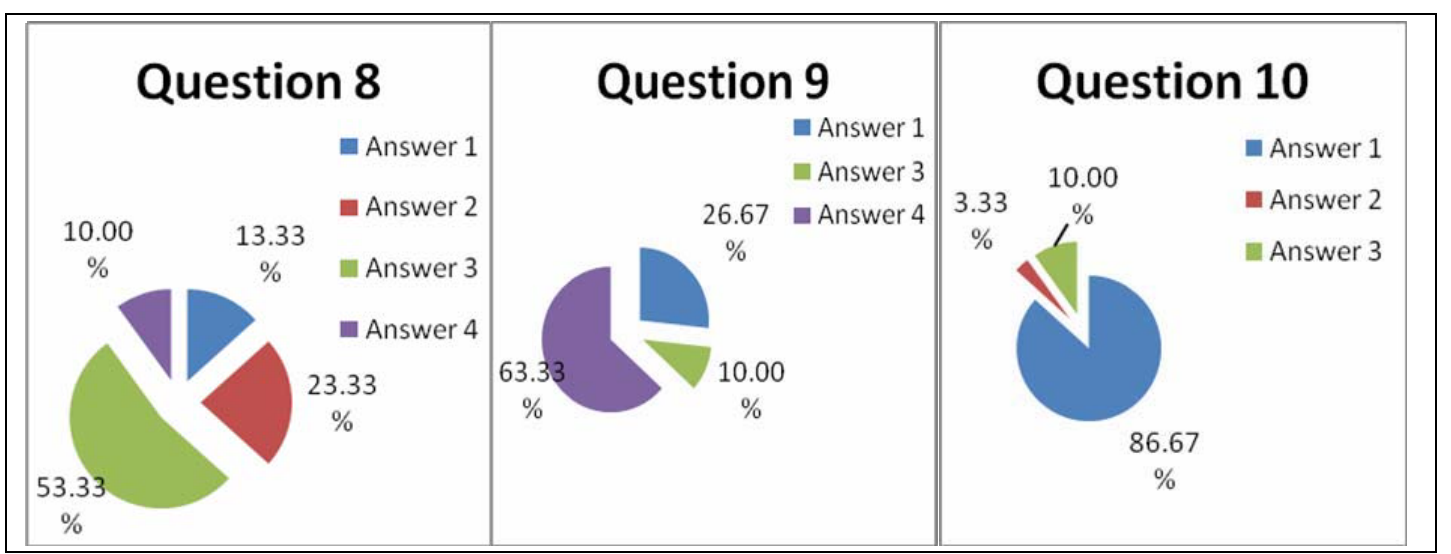

Figure 1. Graphical show of answers to the questions 8, 9, 10 of the questionnaire in Appendix A from all reqruiters 
majority of Albanian companies, based on the results of this study, would not be considered as more qualified than others who were educated in another system. This result seems to put a big question mark to the mission of higher education quality improvement of the Bologna Process.

In the following section is presented a summary and comparative analysis with Table 1 of one segmentation of overall respondents. The subdivision is recruiters of more than ten years of work experience.

7. SUMMARIZED ANALYSIS FOR REQRUITERS WITH 11-15 YEARS WORK EXPERIENCE

An interesting focus of this research is the judgment of employers with 11-15 years recruitment experience. There are two main reasons for this choice. First, it is the long experience in terms of work relations of such individuals that makes particular their way of reasoning. The second lies in the assumption that these individuals are educated and professionally integrated in the early years open market economy (after the 90), which suggests that their way of thinking is fully adapted since the beginning of their careers with the functioning mechanisms and wild spirit of the free market economy.

Twenty per cent of these recruiters, based on the questionnaire in Appendix A of this paper, believe that the Bologna Process worsens the quality of higher education in Albania. Experienced employers seem to rely less in the Bologna process as compared with the whole universe of employers that completed the survey. Almost $10 \%$ of all recruiters in this survey think that the Bologna system worsens the quality of education in Albania.

By observing the statistics of the answers of the last two questions, it is noted that the majority of recruiters with 11-15 years' work experience $(80 \%)$ claim that a master degree as per Bologna Process standards does not differ from an employment perspective from a master degree as per other higher education standards. This is the most significant change in opinion between experienced employers and all employers that are part of this statistics. In Table 1, only $63 \%$ of recruiters think that a master degree as per Bologna Process standards does not properly differentiate employees with the same qualification.

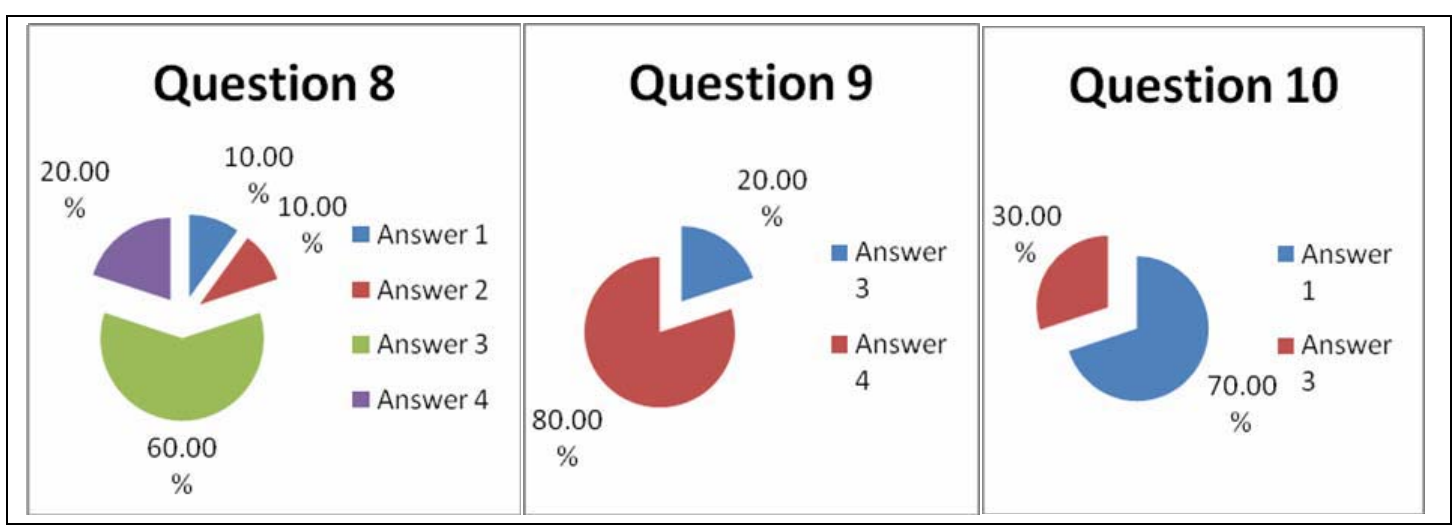

Figure 2. Graphical show of answers to the questions 8, 9, 10 of the questionnaire in Appendix A from reqruiters with 11-15 years work experience 


\section{CONCLUSIONS}

From a global perspective, the Bologna Process seems to have brought innovation in education of the future European citizens. Student and academics mobility and cultural exchange from different countries do improve the level of education by facilitating the comprehensiveness of best practices.

In Albania, as viewed through this study, the Bologna Process appears in its genesis. Continuous changes in the legal framework may have contributed in the confusion of the community and specifically, the "buyer" of this higher education system, Albanian employers. According to the survey analysed in this study, Albanian employers seem to be still doubtful whether the adaption of the Bologna Process standards from most Universities in Albania have enhanced the quality of the master programs and eventually potential employees.

The main result of this study is that, according to employers' opinion, it remains to be observed the quality effectiveness of the master degree as per Bologna Process standards. This because, based on the inferences from the analysis of the survey statistics, such standards seems not to differ in terms of qualification improvement as compared to the other standards of higher education in Albania.

In this context, this research may inspire other studies in the future regarding the effectiveness of adaptation and final product, higher education quality improve, of the Bologna Process in Albania.

\title{
ДА ЛИ ЈЕ БОЛОЊСКИ ПРОЦЕС УНАПРЕДИО СТАНДАРДЕ МАСТЕР СТУДИЈА ? ПЕРСПЕКТИВА ПОСЛОДАВАЦА У АЛБАНИЈИ
}

\author{
Vasilika Kume, Zhaklina Dhamo
}

\begin{abstract}
Извод
Професионална иновација мастер студија, према стандардима Болоњског процеса, представљена је у овом раду и то из перспективе корисника финалних услуга - послодаваца у Албанији. Помоћу упитника, извршен је покушај представљања мишљења послодаваца о квалитету мастер диплома према стандардима Болоњског процеса. Приближно 53\% послодаваца сматра да је Болоњски систем унапредио квалификација запошљених, али да ипак процес треба посматрати дугорочно. Око $87 \%$ послодаваца не сматра да је неопходно платити више запосленог који је стекао мастер ниво образовања према Болоњским стандардима. Овакав запошљени, у већини албанских компанија, не би био сматран више квалификованим у односу на остале колеге који имају образовање стечено претходним системима. Чак шта више, око 20\% послодаваца који имају радно искуство од 11-15 година, верују да је Болоњски процес смањио квалитет образовања у Албанији.
\end{abstract}

Кључна речи: Високо образовање, Болоњски процес, Албански послодавци, Менаџмент људских ресурса 


\section{References}

Albanian Institute for International Studies (2005). The Perceptions of the Academic Community in Albania About the Bologna Process.

Bergan, S. ed., (2003). Recognition issues in the Bologna Process. Strasbourg: Council of Europe Publishing.

Decision No. 303, 01.07.1999. On the establishment of accreditation in the highereducation system. Council of Ministers' of the Republic of Albania.

Decision No. 475, 13.07.2007. On the adoption of wage structure and levels of civil servant, deputy ministers and employees at offices of ministers, line ministries offices, administrate of Precedence, Parliament and Central Commission of Elections. Council of Ministers of the Republic of Albania.

Decision No. 78, 28.01. 2008. On one amendment in the CMD No. 475 dated 13.07.2007 " On the adoption of the wage structure and level of civil servant, deputy ministers and employees of office in the, Council of Ministers, respective ministries' offices, Precedence administrate, Parliament and Central Commission for election. Council of Ministers of the Republic of Albania.

Dima, A., Bratianu, C., Glaser-Segura, D., \& Voges, K. (2011). Bologna Process TradeOffs. The Perception of the Romanian Academic Staff. Management \& Marketing, 6(1):123-138.

Financial Times (2010). Views From the Top: The Bologna Process.

Guideline No. 2, 07.07.2000. On the assessment system of annual individual performance of civil servant. Council of Ministers of the Republic of Albania.

Guideline No. 14, 03.04.2008. For opening and organization of study programs in secondary public institutions. Ministry of Science and Education of the Republic of Albania.

Guideline No. 15, 04.04.2008. On the organization of studies in public institutions of higher education. Ministry of Science and Education of the Republic of Albania.

Law No. 8461, 25.02.1999. On Higher Education in the Republic of Albania. Albanian Parliament.

Law No. 8549, 11.11.1999. On the Status of Civil Servant. Albanian Parliament.

Law No. 9120, 28.07.2003. On some amendments in the Law No. 8461, dated 25.02.1999. On higher Education in the Republic of Albania. Albanian Parliament.

Law No. 9741, 21.05.2007. On Higher Education in the Republic of Albania. Albanian Parliament.

Law No. 10 307, 22.7.2010. On some amendments in the Law No. 9741, dated 21.5.2007. On Higher Education in the Republic of Albania. Albanian Parliament.

Qefalia, A., \& Totoni A. (2012). The Correlation Accreditation - Bologna Process - Continuous Quality Improvement Based in Professors' Perceptions in Albanian Public Universities. Annales Universitatis Apunelis Series Oeconomica, 14(1).

Wylie, I. (2010). The Bologna Accord: A Revolution by Degree, Financial Times. 


\section{APPENDIX A}

\section{Questionnaire}

Dear Ms. /Mr.

The filling of this questionnaire will be done anonymously. None of your credentials will be known to readers of this study.

1. Gender
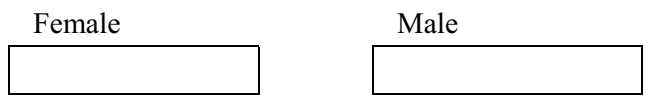

2. Age
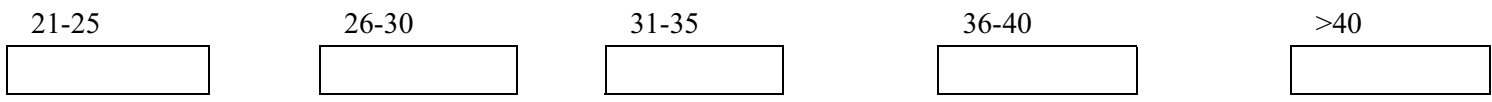

3. Academic Qualification

Elementary

School

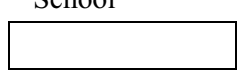

School
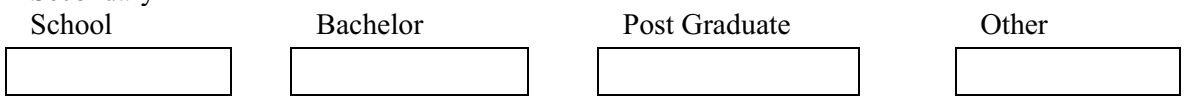

4. Experience (in years)
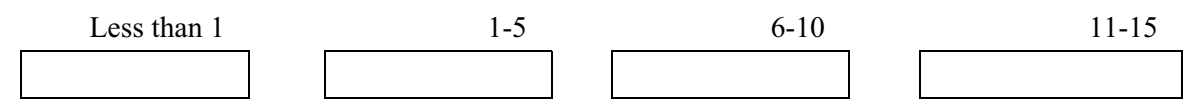

More than 15

5. How many times have you changed job/business?
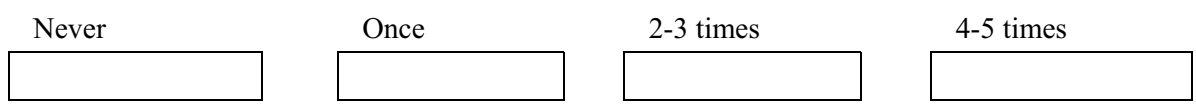

More than 5

times

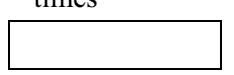

6. How often do you assess the performance of your employees?

\section{Every 1-3 \\ months on \\ average}

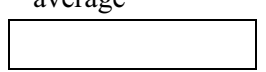

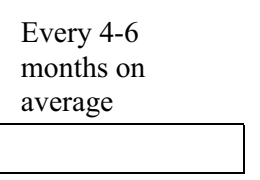

Every 7-12

months on

average

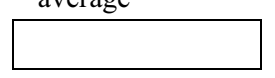

Every $18-24$

months on

average

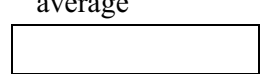

Less frequent than 2 two years

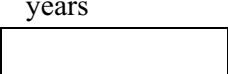

7. Do you have any information about the Bologna Process?
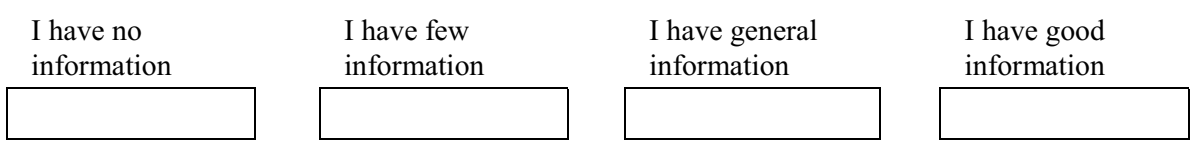

I know very well Bologna

Process 
8. Do you think it improves the Albanian higher education system?
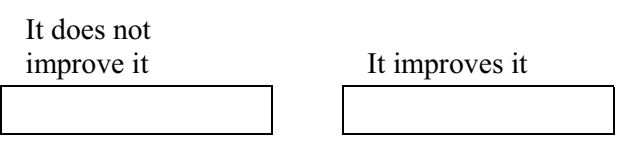

Maybe, but this

should be seen in a

long-term horizon

It worsens it.



9. Would you prefer a young graduate with a master degree as per Bologna Process standards vis-à-vis a young graduate with a master degree before or based on another higher education standard?

\begin{tabular}{|c|c|c|c|c|}
\hline $\begin{array}{l}\text { It does not make } \\
\text { any difference }\end{array}$ & $\begin{array}{l}\text { No, because I } \\
\text { am not clear of } \\
\text { the differences }\end{array}$ & $\begin{array}{l}\text { Yes, because the } \\
\text { Bologna Process } \\
\text { has brought } \\
\text { improvement in } \\
\text { the quality of } \\
\text { qualification }\end{array}$ & $\begin{array}{l}\text { The educational } \\
\text { system does not } \\
\text { make any } \\
\text { difference, it is } \\
\text { the individual } \\
\text { who makes it. }\end{array}$ & $\begin{array}{l}\text { In contrary, a } \\
\text { student } \\
\text { educated as } \\
\text { per the } \\
\text { Bologna } \\
\text { Process } \\
\text { standards is } \\
\text { less qualified } \\
\text { than a student } \\
\text { who has } \\
\text { completed } \\
\text { education } \\
\text { before or in } \\
\text { another } \\
\text { standard. }\end{array}$ \\
\hline & & & & \\
\hline
\end{tabular}

10. What would be the difference in salary (gross) for a young graduate with a master degree as per Bologna Process standards vis-à-vis a young graduate with a master degree before or based on another higher education standard? (in Albanian LEK (ALL))

0

$+5,000$

$+10,000$

$>10,000$

I would pay
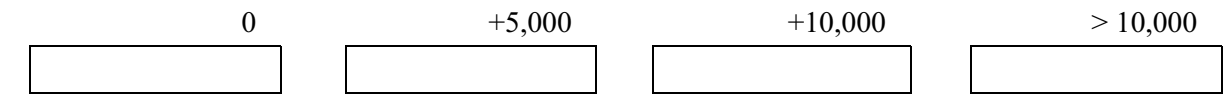

him/her less. 